\title{
EKONOMICKÁ VÝKONNOSş VS. POPULÁCIA V JADRE A HUSTOTA ZAMESTNANOSTI V METROPOLITNÝCH OBLASTIACH KRAJÍN OECD
}

ECONOMIC PERFORMANCE VS. THE CORE POPULATION AND THE EMPLOYMENT DENSITY IN METROPOLITAN AREAS OF THE OECD COUNTRIES

\author{
Ing. Stanislav KOLOĠTa, PhD. \\ Ing. PAula Bolcárová \\ ING. FILIP FLA ĠA, PHD.
}

\author{
Katedra verejnej ekonomiky a regionálneho rozvoja $\mid$ Depart. of Public Economy and Reg. Development \\ Ekonomická fakulta Faculty of Economics \\ Univerzita Mateja Bela v Banskej Bystrici Matej Bel University Banska Bystrica \\ $\bowtie$ Tajovského 10, 97590 Banská Bystrica, Slovak Republic \\ E-mail: stanislav.kolosta@umb.sk,paula.bolcarova@umb.sk,filip.flaska@umb.sk,
}

\begin{abstract}
Anotácia
Cie@̆m !̣ lánku bolo overišpredpoklad, l̦ i ekonomický rast v metropolitných oblastiach krajín OECD bol negatívne ovplyvŔovaný tempom rastu populácie v jadre na celkovom pol te populácie a pozitívne ovplyvŔovaný tempom rastu hustoty zamestnanosti. Výsledky naznal ujú, ǵ medzi metropolitnými oblas Šami OECD sú rozdielnosti, ktoré môğ prameniŠ z ich národnostných ğpecifík spôsobujúcich rozdiely v raste medzi krajinami OECD, kde najviac vy! nievajú Ġaj! iarsko, Kórea a Japonsko, ! o potvrdili aj výsledky popula! ných a priestorovo-zamestnanostných vzŠshov pre metropolitné oblasti OECD. Metropolitné oblasti v rámci ekonomík krajín OECD zohrávajú významnú úlohu a preto si myslíme, ǵe túto oblasડ̌bude vhodné sledovaŠaj v budúcnosti a rozǵriš ju o N̦alğe premenné, l, o je $v$ súl asnosti problém kvôli malému mnoǵstvu ukazovateăv sledovaných za metropolitné oblasti.
\end{abstract}

\section{KŎị̂vé slová}

ekonomická výkonnosŠ populácia v jadre, hustota zamestnanosti, metropolitná oblasŠOECD

\section{Annotation}

The aim of this paper was to verify the assumption that economic growth in metropolitan areas in OECD countries has been negatively affected by the rate of population growth in the MAs core of the total number of MAs population and positively influenced by the growth rate of employment density. The results indicate that among OECD metropolitan areas are differences that might stem from their national specifics causing differences in growth among OECD countries, where the most protruding are Switzerland, Korea and Japan, what was confirmed by the results of population and spatialrelations employment terms to economic growth for OECD metropolitan areas. Metropolitan areas within the economies of OECD countries play an important role and therefore we think that this area will be appropriate to watch in the future and to extend it to other variables, which is currently a problem because of the small number of indicators monitored for metropolitan areas.

Key words economic performance, core population, employment density, metropolitan area of the OECD JEL classification: $R 11, R 12$ 


\section{Úvod}

Ekonomická výkonnosŠ metropolitných oblastí krajín OECD je determinovaná rôznymi faktormi v závislosti od ekonomického prostredia a hospodársko-politickej situácie a stability v danej krajine, kde sa metropolitné oblasti nachádzajú. Za metropolitnú oblasŠ povaǵujeme funkl né mestské územie s poḷ tom obyvateØ̆v viac ako 500000 (OECD, 2013, s. 13). Rôznorodos Š a rozdielna vyspeloš̌ ekonomík krajín OECD má mnoho ! astokrát jedine! ných prí! in. V dôsledku globalizácie svetovej ekonomiky moǵno predpokladaŠ existenciu spolol ných ekonomických tendencií v krajinách OECD. Tie sa môǵu prejavovaŠ práve v metropolitných oblastiach, ktoré sú ekonomicky najvyspelejg̈e, priŠahujú kvalitný Qudský potenciál a populáciu celkovo a sú !̣asto zdrojom impulzov, ktoré sa premietnu do fungovania väl ğch ekonomických celkov. Metropolitné oblasti OECD v rokoch 20002010 prispeli viac ako polovicou v prieme k celkovému ekonomickému rastu OECD (OECD, 2013, s. 34). 33\% celkového ekonomického rastu metropol OECD vyprodukovalo 9 metropolitných oblastí (3.5\% z metropolitných oblastí), $67 \%$ celkového ekonomického rastu metropol OECD vyprodukovalo 264 metropolitných oblastí (96.5\% z metropolitných oblastí). Soul, New York, Tokyo a Londýn prispeli najviac k ekonomickému rastu OECD ako to ilustruje obr. 1.

\section{Obr. 1: Príspevok metropolitných oblastí k celkovému ekonomickému rastu OECD 2000-2010}

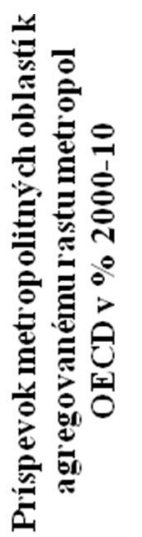

$$
\begin{array}{|c|c|}
\hline 7 & \text { Seoulluncheon (KOR) } \\
\hline 6 & \text { New York (USA) } \\
\hline 5 & \text { Tokyo(JPN) } \\
\hline 4 & \begin{array}{r}
\text { London (GBR) } \\
\text { Los Angeles (USA) }
\end{array} \\
\hline 3 & \text { Washington (US } \\
\hline 2 & \text { Paris (FR } \\
\hline 1 & \text { Houston } \\
\hline 0 & \text { Dal } \\
\hline & \\
\hline
\end{array}
$$$$
\text { New York (USA) }
$$$$
\text { Tokyo (JPN) }
$$$$
\text { London (GBR) }
$$$$
\text { Los Angeles (USA) }
$$$$
\text { Washington (USA) }
$$$$
\text { Paris (FRA) }
$$$$
\text { Houston (USA) }
$$$$
\text { Dallas (USA) }
$$

0

20

40

60

80

100

Agregovaný rast metropolitných oblastí OECD v \% 2000-2010

Zdroj: vlastné spracovanie z údajov www.stats.oecd.org

Metropolitné oblasti môǵeme rozdeliŠ do dvoch hlavných zón ï jadrová a periférna. V niektorých metropolách Mexika a USA pod@̆ prepoḷ ítania populácie v jadre na celkovej populácii existuje len jadrová oblasŠ Jadrová oblasŠ priŠahuje populáciu a Q̆ıdský kapitál. PokiaǑv budúcnosti nedôjde k modifikovaniu politík krajín OECD predpokladá sa výraznejğ pokles podielu pracujúcich (vo veku 15-64) na populácii kvôli nepriaznivému demografickému vývoju (OECD, 2012, s. 16). Táto tendencia sa môǵe týkaŠ aj metropolitných oblastí. Populal ný rast v jadre sa teda nemusí vo vǵeobecnosti prejaviŠ na ekonomickej výkonnosti danej metropolitnej oblasti. Z toho dôvodu skôr predpokladáme negatívny efekt tempa rastu populácie v jadre na celkovej populácii na ekonomickú výkonnosŠmetropolitných oblastí.

Priemerný celkový populal ný prírastok a priemerný populal ný prírastok populácie v jadrových oblastiach sa vyvýjali takmer identicky ako to ilustuje obr. 2 (korelácia na 94,07\%) pril om najvyǵg̉e hodnoty oboch ukazovateळ̆v boli v priemere za obdobie rokov 2000-2012 v jadre ako aj v celej metropolitnej oblasti v mexických a amerických metropolách ako Bueníto Juáres, Austin, Tijuana, Las Vegas, Mcallen. Populą̣ ný úbytok v oboch ukazovateăch bol najvyğğ v metropolách ako Takamatsu, Kurashiki, Bochum, Cleveland, New Orleans, Busan. 
Obr. 2: Priemerný celkový popula! ný prírastok a priemerný popula!̣ný prírastok populácie v jadre metropolitných oblastí OECD2000-2012

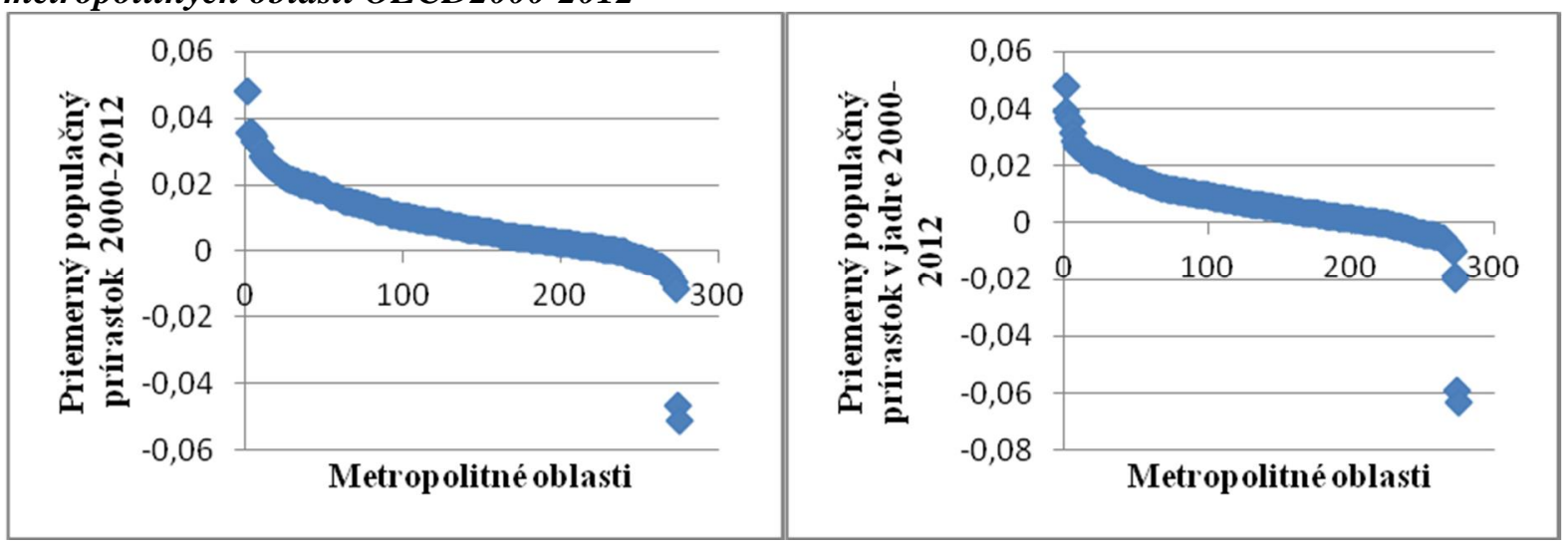

Zdroj: vlastné spracovanie z údajov www.stats.oecd.org

Zapđ̆aním priestoru populáciou v metropolitných oblastiach pri jej sú! asnej ekonomickej prosperite môǵeme predpokladaŠ rast poḷ tu zamestnaných, teda aj rast hustoty zamestnanosti v metropolitnej oblasti, ktorej rast by sa mal pozitívne prejaviŠ aj v ekonomickej výkonnosti kvôli napr. informal nej hustote, hustote formálnych a neformálnych vzŠahov, ekonomickej g̣pecializácii, vysokej produktivite práce a jej efektívnosti (OECD, 2010, s. 34, 46) vzhădom na rozlohovo menğ ekonomický priestor metropolitných oblastí v porovnaní s regionálnou, národnou !̣ i nadnárodnou úrovŔou.

Ekonomická výkonnosŠ sa naj̣ astejg̈e meria prostredníctvom ukazovateŎv ako sú HDP na obyvateă (HDP pc), tempo ekonomického rastu, hrubá pridaná hodnota, produktivita práce, \% ekonomicky aktívneho obyvateQ̆tva, podiel ziskových podnikov na celkovom poḷ te podnikov, priame zahranil né investície v regióne a N̦alg̉e. Ġatistiky OECD na metropolitnej úrovni vykazujú len hlavný ukazovateŎHDP pc resp. HDP.

HDP na obyvateă v roku 2010 malo najvyğg̉e hodnoty v metropolitných oblastiach USA, západnej Európy a Kanady. Najniğǵge hodnoty vykazovali metropolitné oblasti Mexika, Lile, Ǵpanielska. Vo vǵeobecnosti najrýchlejğ ekonomický rast zaznamenali v roku 2010 metropoly USA, Japonska, Mexika, Nemecka, Kanady. Záporný ekonomický rast vykazuje 19 metropolitných oblastí z rôznych krajín, pril om najhorg̉e boli na tom grécke Atény a Thesalonica.

\section{Obr. 3: Vž̌sh HDP na obyvate}

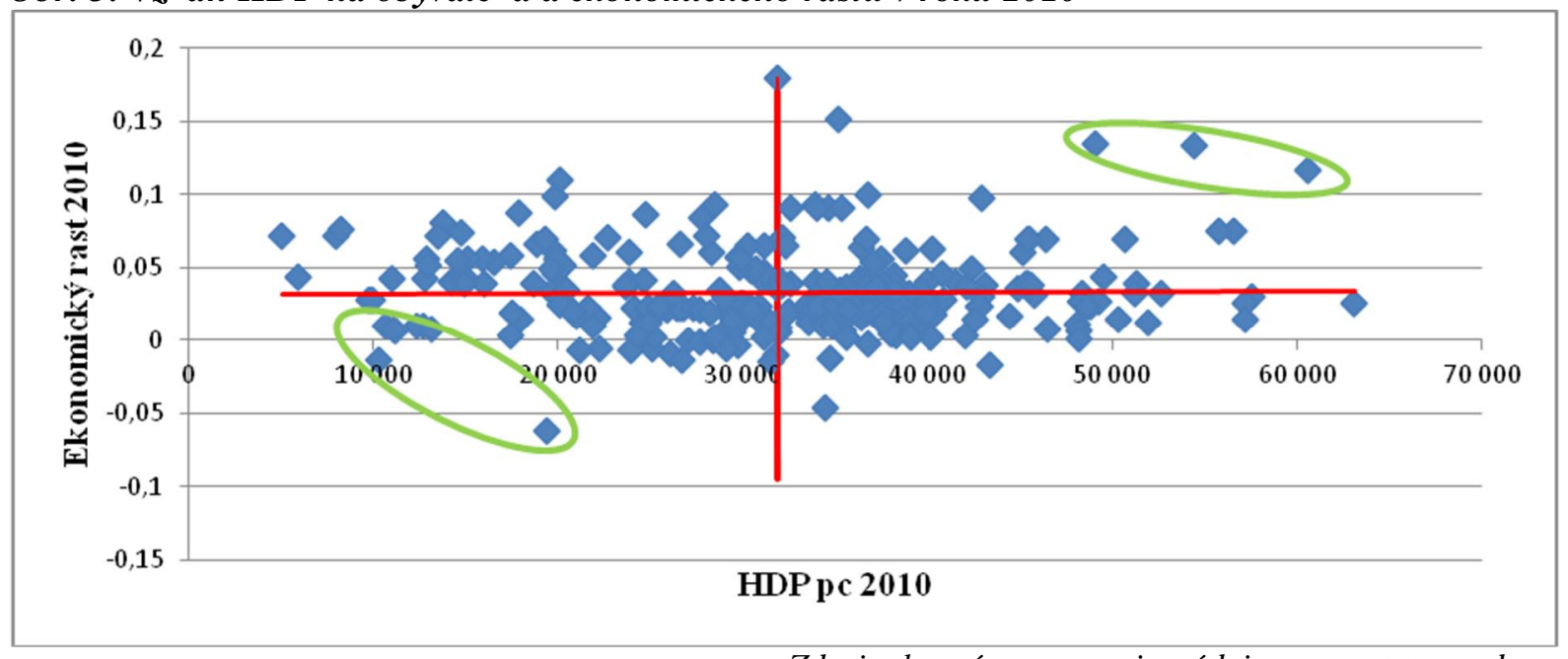

Zdroj: vlastné spracovanie z údajov www.stats.oecd.org 
PodQ̆ priemerných hodnôt HDP pc a ekonomického rastu v roku 2010 sme obr. 3 rozdelili na 4 skupiny ! erveným kríǵm. Napravo od ! ervenej vertikálnej osi bol nadpriemerný ekonomický rast u $41 \%$ metropolitných oblastí krajín OECD a nad horizontálnou ! ervenou osou bolo 52\% metropolitných oblastí s nadpriemerným HDP pc. Vysoké hodnoty oboch ukazovateQ̆v súl asne vykazovali v roku 2010 metropolitné oblasti ako Ulsan, New Orleans a Baton Rouge (elipsa pravý horný roh obr. 3); nízke hodnoty oboch ukazovateQ̆v súl asne boli v roku 2010 v metropolitných oblastiach Thessalonica, Concepción, Valpalasíro, Mexicalli, Tujuana, Juaréz (elipsa Q̆vý spodný roh obr. 3).

\section{Obr. 4: Histogramy HDP na obyvate}

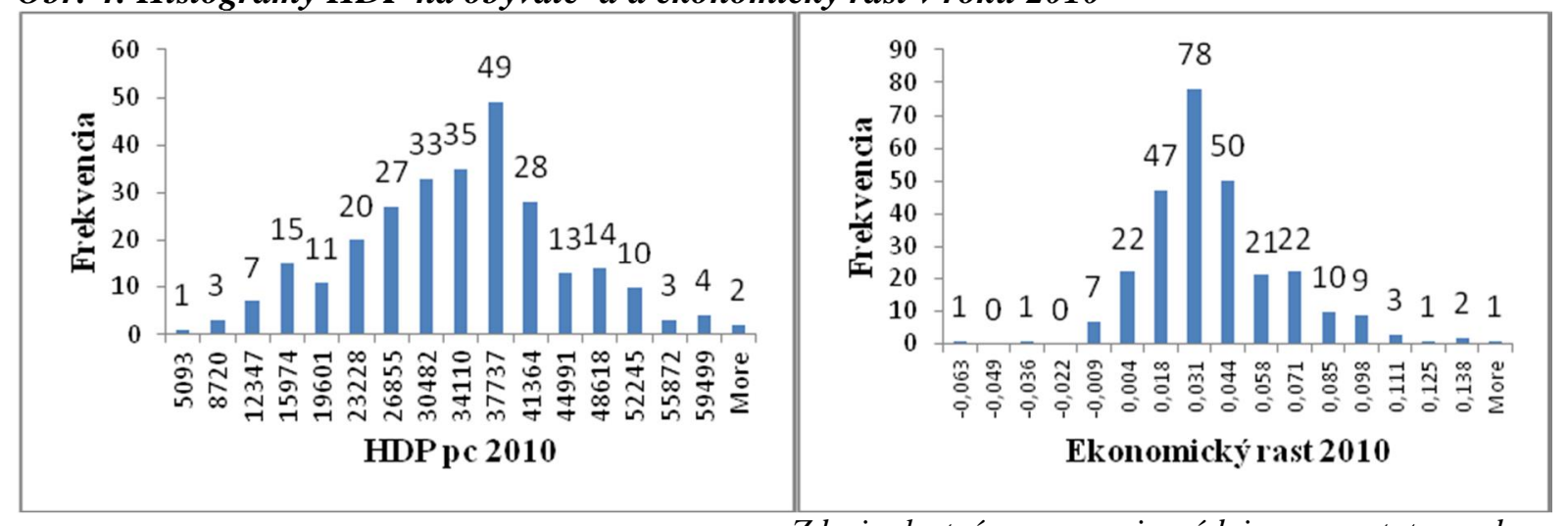

Zdroj: vlastné spracovanie z údajov www.stats.oecd.org

Histogramy rozdelenia HDP pc a ekonomického rastu za rok 2010 na obr. 4 udávajú zastúpenie skupín jednotlivých metropolitných oblastí podă výğky skúmaných ekonomických ukazovateØ̆v. Najviac metropolitných oblastí malo v roku 2010 HDP pc v intervale 34100 ï 37730 USD (tj. cca 18 $\%$ vg̉ttkých metropolitných oblastí) a najpol etnejğ interval v metropolitných oblastiach podQ̆ výğky ekonomického rastu bol v rozmedzí 1,79\% ï 3,1\% (tj. cca 28\% vǵetkých metropolitných oblastí); oba intervaly boli nadpriemerné.

\section{CieOa metódy}

Údaje o ekonomickej výkonnosti, populácii a zamestnanosti sme lerpali z databázy 275 metropolitných oblastí OECD (OECD Regions and cities ï Mertopolitan areas). Viac ako 10 metropolitných oblastí majú krajiny ako USA, Japonsko, Kórea, Mexiko, Nemecko, Francúzsko a VeQ̆á Británia bez ohădu na ich rozlohu. Údaje o populácii v jadre na celkovej populácii a o hustote zamestnanosti boli prepolítané z kompletných dát za skúmané obdobie rokov 2000-2010 (nakoQ̆o údaje o HDP pc boli k dispozícii len do roku 2010). HDP pc bolo pre vǵetky metropolitné oblasti OECD k dispozícii za rok 2010. Priemerné hodnoty ekonomického rastu boli polítané z dostupných údajov, ktoré pred rokom 2010 neboli za vg̉etky metropolitné oblasti OECD kompletne vykazované.

CieQ̆m ! lánku je overiŠ predpoklad, ǵe ekonomický rast (eg) v metropolitných oblastiach krajín OECD je negatívne ovplyvŔovaný tempom rastu populácie $\mathrm{v}$ jadre na celkovom poḷ te populácie (Icore/pop) a pozitívne ovplyvŔovaný tempom rastu hustoty zamestnanosti na $\mathrm{km}^{2}$ (Iempdens) za rok 2010 a tieǵ v priemere za obdobie rokov 2000-2010. TesnosŠ závislosti sme preǵetrili pomocou korelal nej analýzy, pril om sme predpokladali priamu lineárnu závislosŠ medzi ekonomickým rastom a tempom hustoty zamestnanosti a nepriamu lineárnu závislosŠmedzi ekonomickým rastom a tempom rastu populácie v jadre na celkovom poḷ te populácie. VýznamnosŠ korela! ných koeficientov sme testovali na hladine významnosti 0,05 .

Nulová hypotéza predpokladá nulovú lineárnu koreláciu. Kvantifikáciu vplyvu prevedieme prostredníctvom odhadu jednoduchého lineárneho regresného modelu: 


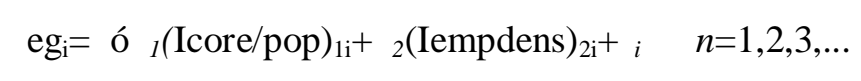

kde eg $g_{i}$ je hodnota ekonomického rastu v $i$-tom regióne, Ǔa $\sigma_{l}$ a $\sigma_{2}$ sú parametre regresnej rovnice, (Icore/pop $)_{1 \mathrm{i}}$ a (Iempdens) $)_{2 \mathrm{i}}$ je hodnota vybraných ukazovateQ̆v populácie a zamestnanosti $\mathrm{v} i$-tom regióne, Ưje náhodná zloǵka modelu a $n$ je poḷ et regiónov.

\section{Výsledky}

Najprv sme sa zamerali na rok 2010, tj. na obdobie po odznení prvých dôsledkov hospodárskej krízy.

Obr. 5: VzŠah ekonomického rastu a tempa rastu populácie v jadre na celkovej populácii a hustoty zamestnanosti v roku 2010

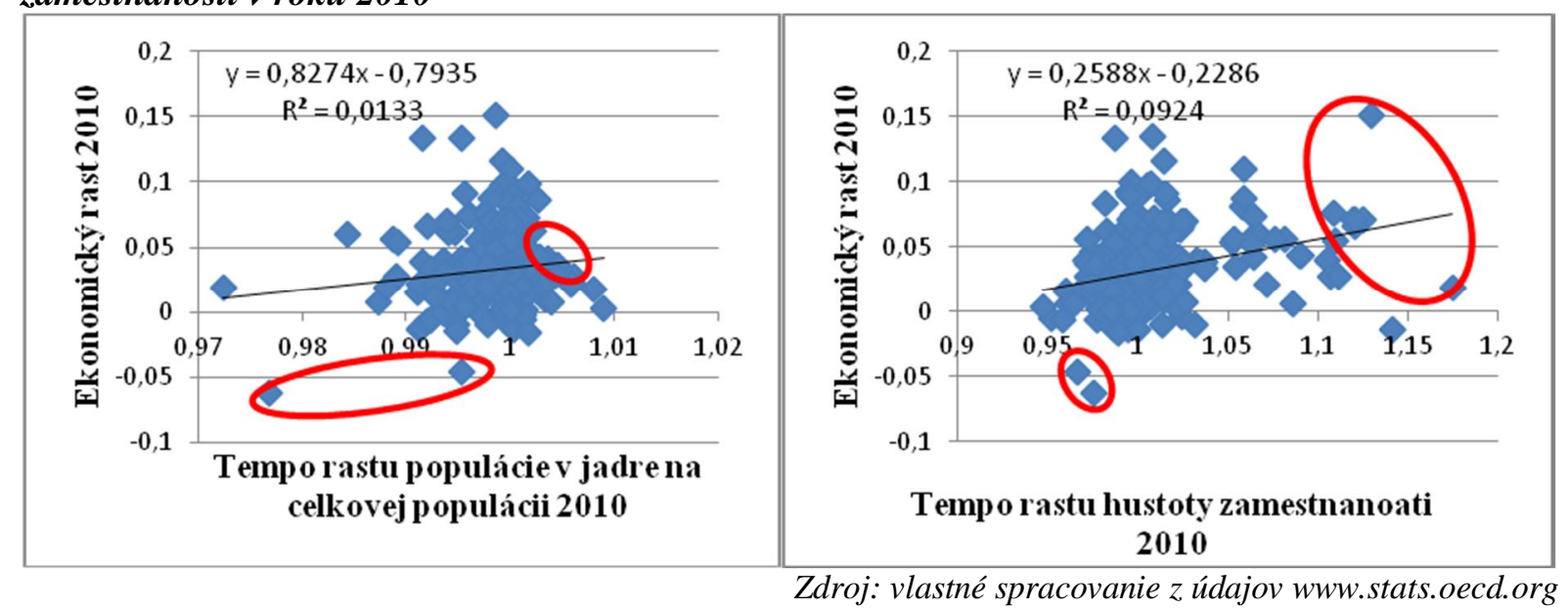

Tab. 1: Výsledky regresie

\begin{tabular}{|c|c|c|c|c|}
\hline Regression Statistics & & & Coefficients & $\mathrm{P}$-value \\
\hline Multiple R & 0,351042 & Intercept & $-1,53561$ & 0,000368 \\
\hline R Square & 0,123231 & Icore/pop2010 & 1,280301 & 0,002205 \\
\hline Adjusted R Square & 0,116784 & Iempdens 2010 & 0,287294 & $1,49 \mathrm{E}-08$ \\
\hline
\end{tabular}

Zdroj: vlastné spracovanie

Tab. 2: Výsledky korelácie

\begin{tabular}{|c|c|c|c|}
\hline & EG2010 & Icore/pop2010 & Iempdens 2010 \\
\hline EG2010 & 1 & & \\
\hline Icore/pop2010 & 0,115431 & 1 & \\
\hline Iempdens 2010 & $\mathbf{0 , 3 0 4 0 4 3}$ & $-0,18725$ & 1 \\
\hline
\end{tabular}

Na základe korela! nej matice pre rok 2010 (tab. 2) moǵno tvrdiŠ ǵe tempo rastu populácie v jadre na celkovej populácii len slabo koreluje s ekonomickým rastom a len mierne slabá korelácia sa preukázala v prípade tempa hustoty zamestnanosti. Oba regresné parametre sú ġatisticky významné, ale variabilitu ekonomického rastu vysvetQ̆ijú len na 12,3\%, !o znamená, ǵe výsledky nemôǵeme zovğeobecniŠ pre vğetky metropolitné oblasti OECD. Najniğǵje hodnoty skúmaných ukazovateQ̆vv v porovnaní s priemernými majú grécke metropolitné oblasti ako Atény, Thessalonica (obr. 5 na grafoch elipsa v spodnej Q avej !̣ati), najvyğg̉e hodnoty v porovnaní s priemernými sú v metropolitných oblastiach Centro, Acapulco de Juaréz, Tuloca, Pachuca de Soto, Léon; mexické metropolitné oblasti vo vǵeobecnosti vykazovali najvyğg̉e hodnoty tempa rastu hustoty zamestnanosti. Výsledky teda poukazujú len na pozitívny vplyv hustoty zamestnanosti na tempo ekonomického rastu metropolitných oblastí OECD v roku 2010. 
ńalej sme zisŠovali, aký bol vzŠah medzi ekonomickým rastom (eg) k tempu rastu podielu populácie $\mathrm{v}$ jadre na celkovej populácii (AVGiCore/pop) a tempu rastu hustoty zamestnanosti (AVGiempdens) metropolitnej oblasti v priemere za obdobie rokov 2000-2010.

Obr. 6: Vz Šah ekonomického rastu a tempa rastu populácie v jadre na celkovej populácii a hustoty zamestnanosti v priemere za roky 2000-2010
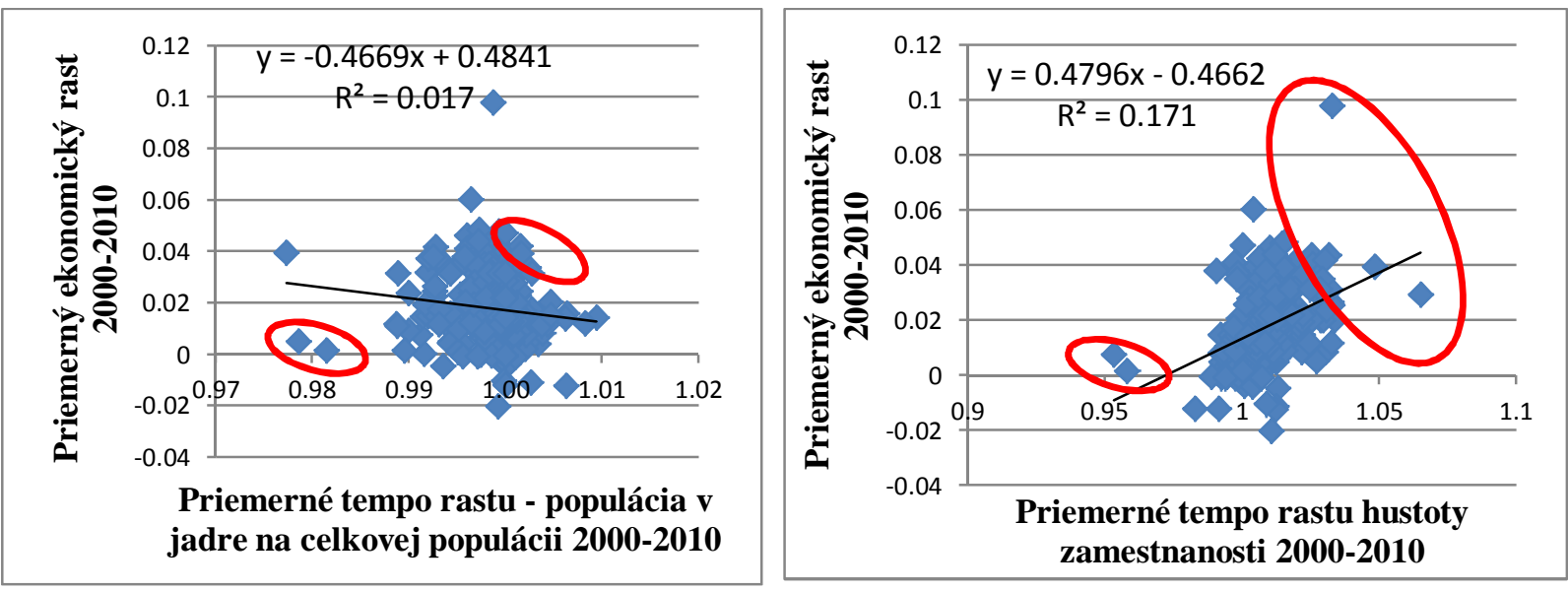

Zdroj: vlastné spracovanie z údajov www.stats.oecd.org

Tab. 3: Výsledky regresie

\begin{tabular}{|c|c|c|c|c|}
\hline Regression Statistics & & & Coefficients & P-value \\
\hline Multiple R & 0,435816 & Intercept & 0,023486 & 0,908649 \\
\hline R Square & 0,189935 & AVGiCore/pop & $-0,49329$ & 0,012276 \\
\hline Adjusted R Square & 0,183979 & AVGiempdens & 0,482464 & $4,2 \mathrm{E}-13$ \\
\hline
\end{tabular}

Zdroj: vlastné spracovanie

Tab. 4: Výsledky korelácie

\begin{tabular}{|c|c|c|c|}
\hline & AVG eg & AVGiCor/tp & AVGiempdens \\
\hline AVG eg & 1 & & \\
\hline AVGiCor/tp & \begin{tabular}{|l|}
$-0,13022$ \\
\end{tabular} & 1 & \\
\hline AVGiempdens & 0,413532 & 0,017725 & 1 \\
\hline
\end{tabular}

V priemere za obdobie rokov 2000-2010 moǵno takmer 19\% zmien v priemernom ekonomickom raste vysvetliŠ zmenou v priemernom tempe rastu podielu populácie vjadre na celkovej populácii a v priemernom tempe hustoty zamestnania. Na základe korela! nej tabuăy (tab. 4) moǵno tvrdiŠ ǵe medzi priemerným ekonomickým rastom a priemerným tempom rastu hustoty zamestnanosti je stredne silná priama lineárna korelácia a len slabá nepriama lineárna korelácia je medzi priemerným ekonomickým rastom a priemerným tempom rastu podielu populácie v jadre na celkovej populácii. Teda ako sme predpokladali, priemerné tempo rastu HDP rástlo s priemerným tempom rastu hustoty zamestnania a bolo zníǵené o priemerné tempo rastu poḷ tu obyvateQ̆tva v jadre, ! o ilustruje obr. 6. Najvyğgie priemerné hodnoty skúmaných ukazovateŎov boli súl asne v Centro, Soul, Mérida, Gwangju ako aj v N̦alğch mexických a kórejských metropolitných oblastiach. Najniğġe hodnoty skúmaných ukazovateQ̆ v boli súl asne v metropolitných oblastiach ako Takamatsu, Kurushiki a Thessalonica.

\section{Záver}

Predpoklad, ǵe ekonomický rast v metropolitných oblastiach krajín OECD je negatívne ovplyvŔovaný tempom rastu populácie $\mathrm{v}$ jadre na celkovom pol te populácie a pozitívne ovplyvŔovaný tempom rastu hustoty zamestnanosti na $\mathrm{km}^{2}$ sa nám potvrdil za významný avğgk skúmané ukazovatele vysvetQ̆ijú 
len $19 \%$ variability priemerného ekonomického rastu. Z toho dôvodu si myslíme, ǵe v skúmaných oblastiach sú medzi metropolitnými oblasŠami OECD rozdielnosti, ktoré môǵa prameniŠ buṆ z ich národnostných g̣pecifík spôsobujúcich rozdiely v raste medzi krajinami (OECD, 2012, s. 11) alebo ǵpecializácie (Bolcárová, Koloğa, Koǵiak, 2013, s. 2) tej ktorej metropolitnej oblasti alebo regiónu (Koğiak, et.al., 2008, s. 3). V oboch prípadoch spomedzi krajín OECD najviac vy! nievajú Ġvajl iarsko, Kórea a Japonsko, ! o potvrdili aj výsledky popula! ných a priestorovo-zamestnanostných vzŞahov (z anglického employment density) pre metropolitné oblasti OECD. Najvyg̈je hodnoty skúmaných ukazovateQ̆v majú kórejské metropolitné oblasti Ulsan, Gwangju, Soul a mexické Centro; najniğgie hodnoty majú japonské Kurushiki a grécka Thessalonica. Napr. v prípade priemerného ekonomického rastu ig̉o o 6 násobný rozdiel, ! o naznal uje veăxé disparity medzi metropolitnými oblasŠami jednotlivých ekonomických celkov, v tomto prípade ázijských.

Nakoăo význam metropolitných oblastí narastá ï a v budúcnosti tomu s najväl ğbu pravdepodobnosŠou kvôli celosvetovým urbanizal ným tendenciám nebude inak (Kamal-Chaoui, Leman, Zhang, 2009, s. 5) ï myslíme si, ǵe túto oblaš̌ bude vhodné sledovaŠ aj v budúcnosti a rozğriŠ ju o N̦alğe premenné napr. aj v súvislosti s benchmarkingom (Meril ková, Nemec, Ġmpíková, 2010; Mikuġová Meril ková, Nemec, 2013) !̣i inteligentným, udrớteĞhým a inkluzívnym rastom (Borseková, Petríková, VaŔová, 2013). ńalg̈e preġetrenie bude závislé od údajovej základne, ktorú eviduje OECD. Tá je v súl asnej podobe zastúpená len malým mnoǵstvom ukazovateŎv (Furceri, Mourougane, 2010, s. 27) o metropolitných oblastiach s nepravidelnou a nekompletnou aktualizáciou, ! o moğno povaǵovaŠza vg̉eobecný jav v mnohých indikátoroch vykazovaných OECD.

\section{Literatúra}

[1] BOLCÁROVÁ, P., KOLOĠTA, S., KOG̣AK, R., (2013). Structural convergence of regions of the SR in relation to innovation strategy and policy of the SR. In 16th International Colloquium on Regional Sciences. Conference Proceedings. Brno: Masarykova univerzita. pp. 182-186. ISBN 978-80-210-6257-3. DOI 10.5817/CZ.MUNI.P210-6257-2013-22.

[2] BORSEKOVÁ, K., PETRÍKOVÁ, K., VAœOVÁ, A., (2013). The role of creative economy in Slovak Republic. AI \& SOCIETY, pp. 1-11, ISSN 0951-5666.

[3] FURCERI, D., MOUROUGANE, A., (2010). Structural indicators: Critical review. OECD Journal: Economic Studies, vol. 2010, iss. 1, pp. 201-234. ISSN 1995-2856.

[4] KAMAL-CHAOUI, L., LEMAN, E., ZHANG, R., (2009). Urban Trends and Policy in China. In OECD Regional Development Working Papers 2009/1. ISSN 2073-7009. p. 70. DOI 10.1787/225205036417.

[5] KOG̣AK, R., ĠFRANCOVÁ, K., URAMOVÁ, M., ĠANTNEROVÁ, ō., MAKANOVÁ, M., ELEXOVÁ, G., (2008). Quantification of regional disparities in Slovakia from aspect of GDP per capita. Arad, In: Studia Universitatis ÄVasile Goldisñ, Seria Stiinte Economice, Anul 18/2008 Partea I, pp. 1-13, ISSN 158-2339.

[6] MERIL KOVÁ, B., NEMEC, J., GUMPÍKOVÁ., (2010). Is the Estonian municipal benchmarking really better? The impacts of research methodology on research results. Public Management Review, vol. 13, iss. 4, pp. 539-550. ISSN 1471-9037.

[7] MIKUǴOVÁ MERIL̦ KOVÁ, B., NEMEC, J., (2013). Contract Management and its Impact on Contracting Public Services: Slovak Republic. Ekonomický ! asopis, vol. 61, iss. 7, pp. 690 ï 700. ISSN 0013-3035.

[8] OECD, (2010). Trends in Urbanisation and Urban Policies in OECD Countries: What Lessons for China?. ISBN 9789264092259 . p. 219.

[9] OECD, (2012). Looking to 2060: Long-Term Global Growth Prospects. OECD Economic Policy Papers. ISSN 2226-583X. p. 31.

[10] OECD, (2013). OECD Regions at a Glance 2013. OECD Publishing. ISBN 978-92-64-12172-0. p. 198. DOI 10.1787/reg_glance-2013-en.

[11] Ġatistické databázy OECD: Dostupné z: 〈www.stats.oecd.org a http://www.oecd-ilibrary.org/statistics〉

\footnotetext{
PŚsp ßek byl zpracován v rámci grantu VEGA 1/0680/14 ĂKreativne odvetvia ako zdroj kŎịlových nehmotných aktív verejného sektora v kontexte inovácii a inteligentného rastuñ
} 